Michael Schulz

Universität Bonn

DOI: 10.15290/std.2017.03.13

\title{
BEYOND BEING: OUTLINE OF THE CATHOLIC HEIDEGGER SCHOOL
}

\begin{abstract}
This paper engages the Catholic Heidegger School's interaction with Heidegger's understanding of Being. Gustav Siewerth, Max Müller, Karl Rahner, Johannes Baptist Lotz, and Bernhard Welte understood that the question of God would be decided with the question of Being with ontological difference. Depending on one's own religious standpoint as well as sympathy for metaphysics, one can dismiss the interaction of the Catholic Heidegger School with Heidegger's philosophy as a Scholastic misunderstanding, a legitimate attempt to further develop the tradition of Scholastic thought or a source of religious-philosophical potential in Heidegger's ontology.
\end{abstract}

Key words: Heidegger, Siewerth, Rahner, Welte, Müller .

\section{Introduction: Heidegger and the Renewal of Philosophy in Catholic Discourse}

In August 1879, Pope Leo XIII published the encyclical Aeterni Patris with the subtitle "On the Restoration of Christian Philosophy in Catholic Schools in the Spirit (ad mentem) of the Angelic Doctor, St. Thomas Aquinas." In light of the diverse philosophical tendencies in the $19^{\text {th }}$ century, the pope's intention was to provide Catholic philosophical and theological thought with orientation in the hope of also being able to influence the intellectual 
climate of Catholic discourse. To this day, it has been attested that Catholic thought orients itself according to Thomas Aquinas (II Vat. Con., Optatam totius, Decree on priestly training, 16). This orientation is, however, no longer a pre-eminent one. In his encyclical Fides ratio from 1998, John Paul II lists many philosophers as points of orientation. Among them is (no. $74^{1}$ ) Antonio Rosmini (1797-1855) who was condemned even 32 years after his death. He was insufficiently Thomistic and had, apparently, read "too much" Kant and Hegel. In 2001, the magisterium corrected its decision. In 2007, he was declared blessed by Pope Benedict XVI. Rosmini's fate makes evident the problematic of the Neo-Scholasticism of the $19^{\text {th }}$ century that was elevated to an "intellectual norm." Seen in this way, one can understand the desire for a renewal. And here, Heidegger's philosophy seemed to offer such a chance. The protagonists of the so-called Catholic Heidegger School seized this opportunity.

In the following remarks, I would primarily like to expound on the Catholic Heidegger School's interaction with Heidegger's understanding of Being. For them it was clear that the question of God would be decided with the question of Being, with ontological difference. The judgment passed on their Heidegger-interpretation was and remains controversial and depends not least of all on one's own religious standpoint as well as sympathy for ontology of being as act and the venerable lady whose name is metaphysics.

\section{The Protagonists of the Catholic Heidegger School}

The label Catholic Heidegger School was coined by the Jesuit and philosopher of religion Erich Przywara (1889-1972) ${ }^{3}$. Among the protagonists of the school, Przywara counted the philosophers Gustav Siewerth (1903-1963) ${ }^{4}$

1 John Paul II, Fides et ratio (Sept. 14th, 1998), №. 74: John Henry Newman, Antonio Rosmini, Jacques Maritain, Étienne Gilson, Edith Stein, Vladimir S. Solov'ev, Pavel A. Florenskij, Petr J. Tschaadaev, and Vladimir N. Lossky.

2 Cf. K.-H. Menke, Lehramtliche Selbstkorrektur. Zur Rehabilitierung von Antonio Rosmini, „Herder-Korrespondenz“ 55 (2001): 457-460.

3 Cf. M. Müller, Auseinandersetzung als Versöhnung. Ein Gespräch über ein Leben mit der Philosophie, ed. W. Vossenkuhl, Berlin: Akademie 1994, pp. 78-79, 82. Müller rejects the Przywara's „label“ Catholic Heidegger School because of the philosophical, ideological and religious difference between Heidegger on one side and Siewerth, Rahner, Lotz, and himself on the other side. Heidegger would not have been their master, rather their stimulator or inspirer (Anreger). - Although Müller's remark is correct, Przywara's designation became famous and identifies, beyond question, these catholic philosophers who appreciated Heidegger as their Anreger.

4 Cf. M. Schulz, Siewerth, Gustav, in: Neue Deutsche Biographie vol. 24, ed. Historischen Kommission bei der Bayerischen Akademie der Wissenschaften und der Bayerischen Staatsbibliothek: München 2010, pp. 394-395; A. Wierciński, Inspired Metaphysics? 
and Max Müller (1906-1994), ${ }^{5}$ the Jesuits Karl Rahner (1904-1984) ${ }^{6}$ and Johannes Baptist Lotz (1903-1992) ${ }^{7}$ as well as the priest and philosopher of religion from Freiburg Bernhard Welte (1906-1983). ${ }^{8}$ With the exception of Welte, these thinkers studied philosophy with Heidegger in Freiburg during the 1930s. Heidegger wrote secondary evaluations for the habilitations of both Siewerth ${ }^{9}$ and Müller ${ }^{10}$ as well as for Lotz' $\mathrm{s}^{11}$ dissertation. The primary supervisor in all cases was Martin Honecker (1888-1941), who read philosophy for theologians. He held the concordat professorship and thus taught with the consent of the Archbishop of Freiburg. Thus, when planning a philosophical career in the Catholic world, Honecker was the right address. Since Honecker declined to take on Rahner's doctoral thesis for reasons which can no longer be ascertained, ${ }^{12}$ Heidegger did not evaluate it. With his academic evaluations,

Gustav Siewerth's Hermeneutic Reading of the Onto-Theological Tradition, Toronto: The Hermeneutic Press, 2003, here 16-30; Urs von Balthasar, A Farewell to Gustav Siewerth, in: A. Wierciński, Between Friends. A Bilingual Edition. The Hans Urs von Balthasar and Gustav Siewerth Correspondence 1954-1963, pp. 156-167.

5 Cf. M. Müller, Auseinandersetzung als Versöhnung; Wilhelm Vossenkuhl, Max Müller (geb. 1906), in: Christliche Philosophie im katholischen Denken des 19. und 20. Jahrhunderts, vol. III: Moderne Strömungen im 20. Jahrhundert, Graz - Wien - Köln: Styra, 1990, pp. 318-327.

6 Cf. T.Sheehan, Karl Rahner: The Philosophical Foundations, Athens, OH: Ohio University Press, 1987; H. Vorgrimler, Understanding Karl Rahner: An Introduction to His Life and ought, New York: Crossroad, 1986.

7 Cf. D. Albarello, La libertà e l'evento. Percorsi di teologia filosofica dopo Heidegger, Milan: Glossa, 2008, pp. 15-94: J. B. Lotz, Il rapporto tra l'essere e l'uomo in prospettiva trascendentale-metafisica; J. B. Lotz, Die ontologische Differenz in Kant, Heidegger und Thomas von Aquin, „Theologie und Philosophie“ 53 (1978): 1-26.

8 Cf. W. Schneider, Bernhard Welte (1906-1983), in: Christliche Philosophie im katholischen Denken des 19. und 20. Jahrhunderts, vol. III, pp. 305-317.

9 Cf. Heidegger's survey on Siewerth in 1937, ed. M. Mohr in: Theologie und Philosophie 63 (1988), pp. 431-432. Heideggers emphasizes the excellent and outstanding level of Siewerth's thought under the condition that one recognizes his catholic standpoint which determines his habilitation (Die Apriorität der Erkenntnis als Einheitsgrund der philosophischen Systematiknach Thomas von Aquin) and other publications. The habilitations was published in a revised form in 1939 under the title Der Thomismus als Identitätssystem. In 1961 Siewerth republished a new version with manifold additions. See now the critical edition G. Siewerth, Gesammelte Werke vol. II: Der Thomismus als Identitätssystem, ed. F.-A. Schwarz, Düsseldorf: Patmos 1979, pp. 5-283.

10 Cf. Müller, Auseinandersetzung als Versöhnung, pp. 52-55.

11 Cf. Zimmermann, Martin und Fritz Heidegger, p. 78.

12 Cf. A. Raffelt, Editionsbericht, in: Karl Rahner, Sämtliche Werke, vol. II: Geist in Welt. Philosophische Schriften, ed. A. Raffelt, Freiburg: Herder, 1995, pp. XIII-XXXVII, here XXIV-XXIX; O. Muck, Heidegger und Karl Rahner, „Zeitschrift für Katholische Theologie“ 
which Heidegger allowed to have political consequences, he successfully prevented Müller ${ }^{13}$ and Siewerth ${ }^{14}$ from taking up academic careers. ${ }^{15} \mathrm{He}$ wrote them off as Catholic thinkers whose production was, while of high quality, neither anything new nor central for the state. Heidegger expressly denounced Müller's critical attitude towards National Socialism. It was only after the war that Müller and Siewerth would receive professorships while, Heidegger, on the other hand, was forbidden to teach. The Jesuits paid no further serious attention to Heidegger's evaluation of Lotz's work, who would go on to have a remarkable career as a philosopher at Jesuit colleges. Rahner switched to theology. In spite of Heidegger's insidious manipulations, which his students could only suspect and which may only have been known to Honecker, they respected his philosophical thought without reservation. Welte, who also came from Meßkirch, became acquainted with Heidegger's philosophy through personal contact with the philosopher. Welte and Heidegger's mothers knew each other well ${ }^{16}$. In Heidegger's last years, above all, Welte was an important conversation partner and confident. He gave the funeral speech at Heidegger's grave. ${ }^{17}$

\section{Heidegger interpretation and individual approaches}

A shared interest in Heidegger does not prevent divergent assessments of his approach. Siewerth and Welte saw in Heidegger the phenomenologist of Being-there, Dasein. Siewerth understood Dasein as empowered and gifted by Being, Sein, which is not, as Heidegger emphasizes, initially grasped through with a concept or Logos, but rather received in an originary intuitus. Before

116 (1994), pp. 257-269; H. Vorgrimler, Karl Rahner. Gotteserfahrung in Leben und Denken, Darmstadt: WBG 2004, pp. 35-40.

13 Cf. H. Vetter, Grundriss Heidegger: Ein Handbuch zu Leben und Werk, Hamburg: Meiner, 2014: 404 .

14 Cf. H. Ott, Gustav Siewerth - Leben im Kontext, in: Gott für die Welt. Henri de Lubac, Gustav Siewerth und Hans Urs von Balthasar in ihren Grundanliegen, ed. P. Reifenberg, A. van Hooff, Mainz: Grünewald 2001, pp. 121-131.

15 Cf. H. Zaborowski, Eine Frage von Irre und Schuld. Martin Heidegger und der Nationalsozialismus, Frankfurt am Main: Fischer 2010, p. 548. The author suggests that Heidegger's critique of Müller's and Siewerth's habilitations refers to their ideological harmlessness; therefore they do not help to resist National Socialist thought.

16 B. Casper, Vorwort, in: Martin Heidegger - Bernhard Welte. Briefe und Begegnungen, ed. A. Denker and H. Zaborowski, Stuttgart: Klett-Cotta 2003, pp. 7-10, here 8.

17 Cf. Martin Heidegger - Bernhard Welte. Briefe und Begegnungen, pp. 148, and 8, 43, 171. 
every conceptus entis there occurs a conceptio entis. ${ }^{18}$ Siewerth opposed, with Heidegger, a philosophy of the subject which overlooks the original thrownness (Geworfenheit) into the world and does not philosophize proceeding from the revealability (Offenbarkeit) of being.

Welte was aware the Heidegger had challenged him "to conceive of thought as phenomenology, that is, as a freeing up and covering of that which shows itself." ${ }^{19}$ Here, it is the "question of the "is" which poses the "great question that arises from the human understanding of being." ${ }^{20}$

Müller positions Heidegger's thought in the context of existentialist philosophy $^{21}$ (Existenzialphilosophie 1964) and confronts Being and Time with the thesis of Being and Spirit: Being is Being-Spirit (intelligibility) and can only therefore be recognized, not because it is temporal ${ }^{22}$. Later Müller substitutes "spirit" for "liberty" and "history" and develops a "metahistory" (Metahistorie) which includes a culturally und pluralistically understanding of being. ${ }^{23}$

Surprisingly, Rahner and Lotz labelled Heidegger a transcendental philosopher. Both interpret him using the coordinates of their older Jesuit brother, Joseph Maréchal (1878-1944). In his work Le point de depart de la métaphysique, Maréchal offered a synthesis of Kant's transcendental approach with scholasticism. ${ }^{24}$ To them, Heidegger also seemed to develop such an approach. The philosopher from Freiburg conceived of the act of cognition and its transcendental conditions as ontological realities. In Being and Time (1927),

18 Cf. Gustav Siewerth, Der Thomismus als Identitätssystem, in: id., Gesammelte Werke vol. II, ed. F.-A. Schwarz, Düsseldorf: Patmos 1979, p. 243; id., Die Analogie des Seienden, in: id., Gesammelte Werke, vol. I, Sein und Wahrheit, ed. F.-A. Schwarz, Düsseldorf: Patmos, pp.451-520, here 458; id., Definition und Intuition, in: ibid., pp. 521-547, here 531; A. Wierciński, Inspired Metaphysics, pp. 188-199.

19 B. Welte, Meister Eckhart. Gedanken zu seinen Gedanken, Freiburg: Herder, 2nd ed. 1992, 25: „Wir verstehen Denken als Phänomenologie, das heißt als ein Freilegen und Bergen des sich selber Zeigenden."

20 Cf. idem, Religionsphilosophie, Freiburg - Basel - Wien: Herder, 2nd ed. 1979, p. 24.

21 Cf. M. Müller, Existenzphilosophie im geistigen Leben der Gegenwart, Heidelberg: Kerle, 3rd ed. 1964.

22 Cf. idem, Sein und Geist. Systematische Untersuchungen über Grundproblem und Aufbau mittelalterlicher Ontologie, München: Alber, 2nd ed. 1981.

23 This new conception becomes evident the 4th edition of his Existenzphilosophie in 1986, p. 292.

24 Cf. J. Lotz, Joseph Maréchal (1878-1944), in: Christliche Philosophie im katholischen Denken des 19. und 20. Jahrhunderts, vol. II. Rückgriff auf scholastisches Erbe, ed. E. Coreth, W. M. Neidl, Graz - Wien - Köln: Styra 1988, pp. 453-469; O. Muck, Die deutschsprachige Maréchal-Schule - Transzendentalphilosophie als Metaphysik: J. B. Lotz, K. Rahner, W. Brugger, E. Coreth u.a., in: Christliche Philosophie im katholischen Denken des 19. und 20. Jahrhunderts, vol. III, pp. 590-622; A. Wierciński, Inspired Metaphysics, pp. 114-117. 
Heidegger explicitly characterized the act of cognition as a mode of Being: "Regarding, understanding and grasping, choosing..." are "modes of being of a particular being, of the being we inquirers ourselves in each case are." 25

\section{The interpretation of Heidegger's critique of the God of metaphysics}

Yet, all these varying appraisals are focused on one question: what is this being around which Heidegger's thought circles? The representatives of the Catholic Heidegger School are aware that the question of God will be decided with this question. And they are also aware of Heidegger's critique of an onto-theological metaphysics. As Heidegger sees it, such a metaphysics places a highest being at the top of a pyramid of that which is. This much is clear: before the causa sui, man can neither fall to his knees in awe nor can he play music and dance before this god. ${ }^{26}$ They know that a Christian theology and philosophy must distance itself from this idea of God and create conceptual space for a confrontation with the living God. Heidegger's critique of the concept of God in metaphysics and theology is thus not conceived of as an atheistic option, regardless of whether, in 1940, Rahner asked "whether Heidegger's system is not the truly philosophical, but also the most radical attempt of an atheistic philosophy." ${ }^{27}$ In contrast, Siewerth warns of an "impatience" regarding the question of God in light of Heidegger's reservation. ${ }^{28}$ In the face of Christian theology as well as philosophy, Heidegger preferred, as he said

25 M. Heidegger, Being and Time, transl. J. Stambaugh, rev. D. J. Schmidt, Albany: State University of New York, 2010, § 3, p. 6.

26 Cf. idem, Identity and Difference, transl. J. Stambaugh, New York - Evanston - London: Harper \& Row, 1969: „Metaphysics is theology in that it thinks Being as the highest ground above all beings, ultimately as the ground of itself, causa sui, which is the metaphysical concept of God. Metaphysics is thus in its very nature onto-theo-Iogic." (p. 15) „.... causa sui. This is the right name for the god of philosophy. Man can neither pray nor sacrifice to this god. Before the causa sui, man can neither fall to his knees in awe nor can he play music and dance before this god. The god-less thinking which must abandon the god of philosophy, god as causa sui, is thus perhaps closer to the divine God. Here this means only: god-less thinking is more open to Him than onto-theo-Iogic would like to admit." (p. 72) Cf. G. Siewerth, Martin Heidegger und die Frage nach Gott, in: id., Gesammelte Werke, vol. III: Gott in der Geschichte. Zur Gottesfrage bei Hegel und Heidegger, ed. A. von Stockhausen, Düsseldorf: Patmos, 1971, pp. 280-293, here 289.

27 Cf. K. Rahner, Einführung in den Begriff der Existentialphilosophie bei Heidegger, in: idem, Sämtliche Werke, vol. II, pp. 317-346, here 342.

28 Cf. G. Siewerth, Martin Heidegger und die Gottesfrage, in: idem, Gesammelte Werke, vol. III, pp. 264-279, here 264. 
"to remain silent in the realm of thinking about God"29. The godless thinking which must abandon the god of philosophy, god as causa sui, is thus perhaps closer to the divine God. Here this means only: god-less thinking is more open to Him than ontotheologic approach would like to admit.

\section{Ontological preparations for the question of God}

The members of the Heidegger school saw these sentences of Heidegger's as a challenge. For Siewerth, it is clear that one can no longer think in timeless categories and conceive of being ahistorically, as was the case in Neo-Scholasticism, such that one always approaches the question of God with the same unchanging ontological considerations. He accepts Heidegger's verdict regarding the oblivion or forgetfulness of being that characterizes metaphysics, excepting Thomas Aquinas. He concurs with Heidegger that one must first open up an ontological ante-chamber, in which the question of God could be posed anew. ${ }^{30}$ Thus, Siewerth, as well as Welte, Lotz, and Müller affirmatively cite the well known passage from the Letter on Humanism, in which Heidegger writes of the indispensable preparation for the question of God: "Only from the truth of being can the essence of the holy be thought. Only from the essence of the holy is the essence of divinity to he thought. Only in the light of the essence of divinity can it be thought or said what the word 'God' is to signify..." 11

In his work The Fate of Metaphysics, Siewerth tries to explore this ante-chamber of knowledge of God indicated by Heidegger and to consider not only the truth of Being but also the essence of the Holy and of Divinity. ${ }^{32}$ Inspired by Heidegger's idea of a history of Being, Siewerth also speaks of the historicity of knowledge of God. ${ }^{33}$ The respective understanding of being is decisive for the question of God. Because being shows, hides and reveals itself in different ways from epoch to epoch, the ontological approaches to God are also differ-

29 M. Heidegger, Identity and Difference, p. 55.

30 Cf. Siewerth's above mentioned article on the question of God in Heidegger's thougt (Sämmtliche Werke, vol. III, pp. 264-279, 280-293), and cf. G. Siewerth, Schicksal der Metaphysik von Thomas bis Heidegger, Freiburg: Einsiedeln, 2003, pp. 27-29, 33-36, 68-70, 77-78, 594-603, 660-664.

31 M. Heidegger, Letter on ,Humanism', in: id.,: Pathmarks, ed. W. McNeill, Cambridge: University Press, 1998, pp. 239-276, here 267. Cf. B. Welte, Auf der Spur des Ewigen, Freiburg - Basel - Wien: Herder, 1965, pp. 275-276; J. B. Lotz, Martin Heidegger und Thomas von Aquin. Mensch - Zeit - Sein, Pfullingen 1975, pp. 37-38; Siewerth, Schicksal der Metaphysik, pp. 465-470, 534-552; Müller, Existenzphilosophie, p. 70.

32 Cf. G. Siewerth, Schicksal der Metaphysik, pp. 535-560, 634.

33 Ibidem, pp. 77-78. 
ent, sometimes easily accessible and at other times closed. When access to reality is characterized, above all, by technique (Technik), ${ }^{34}$ as is the modernity diagnosed by Heidegger, it becomes difficult in this man-made world to come in contact with a reality that points to something beyond this made world. For this reason, in many of his texts, Siewerth endeavors to call attention to the marvelous and exuberant character of being in order to reveal the traces of transcendence. Thus, in order to show that the world is neither merely technically produced nor simply a reality made and manufactured by some creator, he attempts to open up an uncreated, non-made, indeed, groundless dimension of the created. Siewerth cites the Silesian mystic Angelus Silesius (1624-1677) who once wrote that "The rose is without why; it blooms because it blooms." 35 In other words, the rose is simply there, blossoming, without providing any why, any reason, free of purpose. Thus, the rose points beyond itself to God's lack of grounding and of cause. God is not causa sui.

It is the mystical poet to whom the philosopher ultimately listens - just as Heidegger listened to Hölderlin. Heidegger's Hölderlin-interpretations resonated deeply with Siewerth. He opens himself up to the poet's symbols and signs, like that of the cloud. Thus, the cloud is only itself when pointing to that "which it itself no longer is," namely, to the sky, that is, clarity. ${ }^{36}$

Ultimately, Siewerth's thought has room for Heidegger's Adventist-eschatological thought of a coming, divine God that itself manifests thought and does not depend on the intelligence and cleverness of philosophers when doing so. ${ }^{37}$ One could even understand this assumption of Siewerth as an echo of protestant skepticism regarding Scholastic proofs of God. And, indeed, Heidegger-reception ran into massive opposition within Catholicism. Instead of clear and distinct concepts there were now roses and clouds or even the transcendental à la Kant, decorated with Heidegger's enigmatic idioms. This neither pleased nor convinced any "true Neo-Scholastic." Müller, Welte, Lotz, and Rahner had to struggle with their opponent's reservations.

But, even Siewerth ultimately asked why Heidegger himself did not more clearly indicate that Being had to be transcended to an ultimate dimension

34 Cf. even J. B. Lotz, Heidegger und Thomas, pp. 20-21, 27-28.

35 Angelus Silesius, Cherubinischer Wandermann, Einsiedeln: Johannes, 2nd ed. 1980, p. 83; cf. M. Heidegger, The Principle of Reason, transl. R. Lilly, Bloomington and Indianapolis: Indiana University Press, 1996, pp. 35-37; G. Siewerth, Thomismus, p. 142; idem, Über das Wunderbare, in: id., Hinführung zur exemplarischen Lehre, Freiburg - Basel - Wien: Herder, 1965, pp. 74-80; cf. H. Verweyen, Ontologische Voraussetzungen des Glaubensaktes, Düsseldorf: Patmos, 1969, pp. 178-181.

36 G. Siewerth, Schicksal der Metaphysik, pp. 531-532.

37 Ibidem, pp. 652-653, 664-667. 
of reality, whether or not exact knowledge thereof might be reserved for a future, eschatological self-expression of God. ${ }^{38}$ And how could such a step beyond Being be grounded?

\section{Being and transcendence}

To answer this question I will begin by summarizing Rahner's thought. Regarding Heidegger's understanding of Being, Rahner agrees "that in its being this being is concerned about its very being." ${ }^{39}$ The Jesuit adopts and interprets Heidegger's connecting of the human subject as Dasein with transcendence; in his essay "On the Essence of Ground," Heidegger states "to be a subject means to be a being in and as transcendence." ${ }^{40}$ Rahner's entire thought is aimed at grasping the human being as the essence of transcendence, as an essence that transcends that which is and which is only a free subject in so far as it transcends everything. ${ }^{41}$ But to what end does this transcendence take place?

Heidegger argues that the goal of transcendence "is usually, though inaccurately, called the 'transcendent."' 42 According to Heidegger, only a reference to the world correctly describes transcendence. He defines "transcendence as being-in-the-world." ${ }^{43}$ But the Catholic philosophers want to go beyond this world - to heaven on a cloud... Heidegger understands the world as that which is in its entirety. To this finite world also belongs a - finite - heaven that is sky.

But, the human being only grasps that which is in its entirety when, in anxiety, as Heidegger said in his lecture What is Metaphysics?, it slips and "sinks" away and nothingness becomes dominant. Nothingness reveals the entirety of that which is, of beings, grounding transcendence. Thus, regarding Dasein

38 Cf. G. Siewerth, Schicksal der Metaphysik, pp. 581-582; A. Wierciński, Inspired Metaphysics, pp. 118-130.

39 M. Heidegger, Being and Time, § 4, p.10. K. Rahner, Theologie der Freiheit, in: id., Schrift zur Theologie, vol. VI, ed. Zürich - Einsiedeln - Köln: Benziger, 2nd ed. 1968, pp. 215-237, here 223, paraphrases Heidegger's definition in the following terms: "the human being is that being that, in its being, is concerned about its very being, that always already has a relationship to itself, that is subjectivity and never just nature, always already person..."; "...der Mensch ist jenes Seiende, dem es in seinem Sein um dieses selber geht, das immer schon ein Verhältnis zu sich selbst hat, Subjektivität und nie einfach Natur, immer schon Person..."

M. Heidegger, On the Essence of Ground, in: id., Pathmarkes, pp. 97-137, here 97. transl. W. V. Dych, New York: Crossroad 1999, pp. 17-21, 31-35.

42 M. Heidegger, On the Essence of Ground, p. 107.

43 We name world that toward which Dasein as such transcends, and shall now determine transcendence as being-in-the-world. 
that exists as transcendence, Heidegger can say that "Dasein means: being held into nothing." ${ }^{44}$ In mystical language, Heidegger formulates the thought that Nothing, the Nichts, becomes clear night, it brings about Dasein first of all, before any kind of being. ${ }^{45}$ It is nothingness which makes possible a relationship to all that which is and thus makes possible freedom - constituting human Dasein. ${ }^{46}$

Being (Sein) too can only be grasped within the horizon of nothingness. For, like beings, "being itself is essentially finite," for which reason it reveals itself only in the transcendence of Dasein which is held out into the nothing. ${ }^{47}$ Thus, it is not being, but rather the nothingness, the Non-Being (Nichts) which grounds transcendence.

\section{Nothing or Being as condition of Transcendence}

Using thoroughly scholastic means the philosophers of the Catholic Heidegger School attempted to prove the contrary. Müller and Rahner insisted on there being something more which must exist in order to explain how the human being can conceive of and transcend that which is, beings, in its finitude. It is impossible to move beyond beings by means of something less than that which is, namely, by means of nothingness. Rahner, who also characterizes the transcending movement of the intellect with the expression 'anticipation', Vorgriff, thus states that “...the Vorgriff towards nothingness is an unverifiable ... hypothesis." ${ }^{\prime 8}$ The nothingness of the finite is therefore not grasped by means of nought, but rather the infinite. It is not nought which lets beings "sink" and disappear, but rather an unlimited Being: "Hence it is not

$44 \quad$ M. Heidegger, What is Metaphysics?, An interpretive translation by Thomas Sheehan, https:// religiousstudies.stanford.edu/wp-content/uploads/1929-WHAT-IS-METAPHYSICS2013-NOV.pdf, p. 9.

45 Idem, What is Metaphysics?, p. 9: „In the clear night of the no-thing experienced in dread, there occurs the original revelation of the meaningfulness of things: the fact that things are meaningful and are not the no-thing. But this "and-are-not-the-no-thing" is not some later clarification. It comes first; it is what makes possible all disclosure of things as meaningful. In its essence the no-thing as pushing us back stands at the origin and consists in letting us encounter for the first time things insofar as they are meaningful.“ Ibidem, p.9: „Without the original revelation of the no-thing, there is no selfhood and no freedom."

47 Ibidem, p. 13: ,... being itself is essentially finite and shows up only in the human being's transcendence, its being held out into the no-thing."

48 Cf. K. Rahner, Hearer of the Word, trans. J. Donceel, ed. A. Tallon, New York: Continuum 1994, p. 50. 
,nought that noughtens', but the infinity of being, at which the Vorgriff aims, that unveils the finiteness of all that is immediately given." 49

For Müller, Rahner and Lotz, this infinitude of Being is at the same time a hint towards a Being of infinite reality. ${ }^{50}$ While the infinite Being, towards which the human being transcends beings, is not immediately God, it does point to God. If this infinite Being were God, God would immediately belong to the self-realization of the human being as the essence of transcendence, something which contradicts the Christian concept of God. ${ }^{51}$ But what is this infinite Being which is not God and yet also more and other than that which is?

\section{Being as giving, being as "unreal" act}

In order to clarify the identity of infinite Being, Müller, Siewerth, Lotz and Welte pursued the considerations offered by Heidegger about the sentence "'there is / it gives' ['es gibt'] being" in the Letter on Humanism and the lecture Time and Being ${ }^{52}$. Welte saw in this formulation the thought of a giving that guarantees beings ${ }^{53}$. According to Müller, this giving being is, indeed, "a reality." But as a giving reality, he adds, its actuality lies "only in that which it made possible" (66), in that which is, in beings. ${ }^{54}$ Being reveals itself as "making possible" and is even a gift to thought - whereupon thought transcends.

For this reason, Müller compares Heidegger's understanding of Being to the scholastic conception of the actus essendi, which is neither God nor beings, but rather only the given gift of the existence of beings. The actus essendi is reality, but Being is only actuality in that which is and as that which is. ${ }^{55}$

$49 \quad$ K. Rahner, Hearer of the Word, p. 50; id., Spirit in the World, pp. 184-187; id., Foundations of Christian Faith, pp. 33-34.

50 Cf. M. Müller, Existenzphilosophie, p. 68; K. Rahner, Spirit in the Word, p. 181: „the pre-apprehension (Vorgriff) attains to God"; idem, Hearer of the Word, pp. 51-54; idem, Foundations of Christian Faith, pp. 51-71; J. B. Lotz, Heidegger und Thomas, pp. 67-75, 82-90.

51 Cf. K. Rahner, Spirit in the Word, 181: „This esse apprehended in the pre-apprehension is ... in itself esse ,commune' ...; G. Siewerth, Das Sein als Gleichnis Gottes, in: idem, Gesammelte Werke, vol. I, pp. 651-685, here 667. Philosophizing with Gustav Siewerth, Das Sein als Gleichnis Gottes: Being as Likeness of God, transl. and ed. A. Wierciński, Konstanz: Gustav-Siewerth-Gesellschaft, 2005, pp. 44-45.

52 Cf. M. Heidegger, Humanism, p. 254; id., On Time and Being, transl. J. Stambaugh, New York: Harper \& Row, 1972, p. 8.

53 Cf. B. Welte, Auf der Spur des Ewigen, p. 276.

54 M. Müller, Existenzphilosophie, p. 66.

55 Ibidem, pp. 67-68. 
Siewerth offers an identical interpretation. ${ }^{56} \mathrm{He}$ understands the actus essendi as actuality and beings as reality. Thomas Aquinas is the source he calls upon for his ontology. In De potentia, Thomas offers the definition: "esse significant aliquid simplex et completum, sed non subsistens" (De potentia q. 1, a.1.). Siewerth concludes from this quote that subsistence and reality are a privilege of God and beings. Precisely Being, on the other hand, does not subsist in its simplicity and perfection. It is, however, the act that constitutes the reality of beings. ${ }^{57}$

Siewerth fears that, if one does not tie the Being which Heidegger considered an enabling giving back to a divine giver, one runs the danger of hypostatizing Being, that is, of equating it with something that is, in order to avoid having to say that something unreal or non-subsisting might bring forth something real. Thus, it is only this tying back of Being to God which ensures the ontological difference between Being and beings invoked by Heidegger and which, in other words, guards one from the forgetfulness of being. The punchline of Siewerth's argument thus lies in the idea that Heidegger himself is doomed to the 'forgottenness' of being if he refuses to take the step to God. As such, his "There is being," "Es gibt Sein," "It gives being," implies this step out of the ontological difference to the ontological identity of act and reality in God: it is this God who gives being. ${ }^{58}$

\section{The ambivalence of nothingness}

Welte made another, more practical suggestion regarding how to ground transcendence. While he adopted Heidegger's thesis on man as the placeholder of nothingness, according to Welte, nothingness has two sides. It can signify absolute destruction, that is, death. But, it can also make itself visible as that "veil of being" of which Heidegger speaks in the afterword to his lecture "What is Metaphysics?": as the veil of a comprehensive meaning constituted by an infinite, mysterious power. ${ }^{59}$ According to Welte, life itself speaks for this second possibility. ${ }^{60}$ Whoever lives also acts and presupposes meaning in doing so - meaning being a category foreign to Neo-Scholasticism and which it did

$56 \quad$ A. Wierciński, Inspired Metaphysics, pp. 167-188.

57 Cf. G. Siewerth, Sein als Gleichnis Gottes, p. 673; Being as Likeness of God, p. 52; A. Wierciński, Inspired Metaphysics, pp. 36-41.

58 Cf. G. Siewerth, Schicksal der Metaphysik, pp. 581-585, 587; A. Wierciński, Inspired Metaphysics, pp. 204-206.

59 Cf. B. Welte, Religionsphilosophie, pp. 45-75; Cf. G. Siewerth, Schicksal der Metaphysik, pp. 585-587: „Die Nichtigkeit des Seins bei Heidegger“.

60

Cf. B. Welte, Religionsphilosophie, pp. 62-63. 
not connect to Being. Every person presupposes an all-encompassing meaning which, consciously or unconsciously, acts against injustice, suffering and strife and, in doing so, counts on there being values which not even a complete meaninglessness could render meaningless. This person counts on an infinite, mysterious power that - in contrast to the finite human being - can guarantee a comprehensive meaning. Thus, in the nothingness into which finite Dasein stretches, absolute Being hiddenly reveals itself as comprehensive meaning. Being as comprehensive, infinite meaning thus grounds the transcendence of Dasein above and beyond the merely meaningless nothingness.

\section{Beyond being: God}

To put it briefly, according to Welte, it is Being as meaning that decides the question of God. For Müller, Rahner and Lotz, it is Being as the something that is more than beings and to which the human being relates - transcending beings - that decides the question of God. For Siewerth, it is the poet's Being, symbols and signs, clouds and skies, as well as Being as actus essendi, as the differential-unity of act and reality that decide the question of God. Yet, none of the thinkers named contested Heidegger's thesis that the final decision regarding the question of God remains reserved for the coming of the divine God.

In closing: one can dismiss the interaction of the Catholic Heidegger School with Heidegger's philosophy as a Scholastic misunderstanding. One can call it eclectic or syncretic and let the products of its thought disappear as a hybrid creature in the archives of the history of philosophy. Or one can recognize in this hybridity a legitimate attempt to further develop the tradition of Scholastic thought. And lastly, one can also discuss the extent to which the Catholic Heidegger School may have discovered a source of religious-philosophical potential in Heidegger's ontology: The being of beings as an objective and real hint toward an absolute being; in different cultures this being has to be deciphered differently.

\section{Bibliography:}

1. Albarello D., La libertà e l'evento. Percorsi di teologia filosofica dopo Heidegger, Milan: Glossa, 2008.

2. Angelus Silesius, Cherubinischer Wandermann, Einsiedeln: Johannes, 2nd ed. 1980. 
3. Balthasar U. von, A Farewell to Gustav Siewerth, in: A. Wierciński, Between Friends. A Bilingual Edition. The Hans Urs von Balthasar and Gustav Siewerth Correspondence 1954-1963.

4. Casper B., Vorwort, in: Martin Heidegger - Bernhard Welte. Briefe und Begegnungen, ed. A. Denker and H. Zaborowski, Stuttgart: Klett-Cotta 2003, pp. 7-10, here 8.

5. Heidegger M., Being and Time, transl. J. Stambaugh, rev. D. J. Schmidt, Albany: State University of New York, 2010.

6. Heidegger M., Identity and Difference, transl. J. Stambaugh, New York - Evanston - London: Harper \& Row, 1969.

7. Heidegger M., Letter on ,Humanism', in: M. Heidegger, Pathmarks, ed. W. McNeill, Cambridge: University Press, 1998.

8. Heidegger M., On the Essence of Ground, in: M. Heidegger, Pathmarkes.

9. Heidegger M., On Time and Being, transl. J. Stambaugh, New York: Harper \& Row, 1972.

10. Heidegger M., The Principle of Reason, transl. R. Lilly, Bloomington and Indianapolis: Indiana University Press, 1996.

11. Heidegger M., What is Metaphysics?, An interpretive translation by Thomas Sheehan, https://religiousstudies.stanford.edu/wp-content/uploads/1929-WHAT-IS-METAPHYSICS-2013-NOV.pdf.

12. Heidegger's survey on Siewerth in 1937, ed. M. Mohr in: Theologie und Philosophie 63 (1988).

13. John Paul II, Fides et ratio (Sept. 14th, 1998).

14. Lotz J. B., Il rapporto tra l'essere e l'uomo in prospettiva trascendentale-metafisica. Die ontologische Differenz in Kant, Heidegger und Thomas von Aquin, „Theologie und Philosophie" 53 (1978).

15. Lotz J. B., Martin Heidegger und Thomas von Aquin. Mensch - Zeit - Sein, Pfullingen 1975.

16. Lotz J. B., Joseph Maréchal (1878-1944), in: Christliche Philosophie im katholischen Denken des 19. und 20. Jahrhunderts, vol. II. Rückgriff auf scholastisches Erbe, ed. E. Coreth, W. M. Neidl, Graz - Wien - Köln: Styra 1988.

17. Menke K.-H., Lehramtliche Selbstkorrektur. Zur Rehabilitierung von Antonio Rosmini, „Herder-Korrespondenz“ 55 (2001).

18. Muck O., Die deutschsprachige Maréchal-Schule - Transzendentalphilosophie als Metaphysik: J.B. Lotz, K. Rahner, W. Brugger, E. Coreth u.a., in: Christliche Philosophie im katholischen Denken des 19. und 20. Jahrhunderts, vol. III.

19. Muck O., Heidegger und Karl Rahner, „Zeitschrift für Katholische Theologie“ 116 (1994).

20. Müller M., Auseinandersetzung als Versöhnung. Ein Gespräch über ein Leben mit der Philosophie, ed. W. Vossenkuhl, Berlin: Akademie 1994.

21. Müller M., Auseinandersetzung als Versöhnung; Wilhelm Vossenkuhl, Max Müller (geb. 1906), in: Christliche Philosophie im katholischen Denken des 19. und 20. Jahrhunderts, vol. III: Moderne Strömungen im 20. Jahrhundert, Graz - Wien - Köln: Styra, 1990.

22. Müller M., Existenzphilosophie im geistigen Leben der Gegenwart, Heidelberg: Kerle, 3rd ed. 1964. 
23. Müller M., Sein und Geist. Systematische Untersuchungen über Grundproblem und Aufbau mittelalterlicher Ontologie, München: Alber, 2nd ed. 1981.

24. Ott H., Gustav Siewerth - Leben im Kontext, in: Gott für die Welt. Henri de Lubac, Gustav Siewerth und Hans Urs von Balthasar in ihren Grundanliegen, ed. P. Reifenberg, A. van Hooff, Mainz: Grünewald 2001.

25. Raffelt A., Editionsbericht, in: Karl Rahner, Sämtliche Werke, vol. II: Geist in Welt. Philosophische Schriften, ed. A. Raffelt, Freiburg: Herder, 1995.

26. Rahner K., Einführung in den Begriff der Existentialphilosophie bei Heidegger, in: K. Rahner, Sämtliche Werke, vol. II.

27. Rahner K., Foundations of Christian Faith. An Introduction to The Idea of Christianity, transl. W. V. Dych, New York: Crossroad 1999.

28. Rahner K., Hearer of the Word, trans. J. Donceel, ed. A. Tallon, New York: Continuum 1994.

29. Rahner K., Theologie der Freiheit, in: K. Rahner, Schrift zur Theologie, vol. VI, ed. Zürich - Einsiedeln - Köln: Benziger, 2nd ed. 1968.

30. Schneider W., Bernhard Welte (1906-1983), in: Christliche Philosophie im katholischen Denken des 19. und 20. Jahrhunderts, vol. III.

31. Schulz M., Siewerth, Gustav, in: Neue Deutsche Biographie vol. 24, ed. Historischen Kommission bei der Bayerischen Akademie der Wissenschaften und der Bayerischen Staatsbibliothek: München 2010.

32. Sheehan T., Karl Rahner: The Philosophical Foundations, Athens, OH: Ohio University Press, 1987.

33. Siewerth G., Das Sein als Gleichnis Gottes, in: G. Siewerth, Gesammelte Werke, vol. I.

34. Siewerth G., Das Sein als Gleichnis Gottes: Being as Likeness of God, transl. and ed. A. Wierciński, Konstanz: Gustav-Siewerth-Gesellschaft, 2005.

35. Siewerth G., Definition und Intuition, in: G. Siewerth, Gesammelte Werke, vol. I, Sein und Wahrheit, ed. F.-A. Schwarz, Düsseldorf: Patmos.

36. Siewerth G., Der Thomismus als Identitätssystem, in: id., Gesammelte Werke vol. II, ed. F.-A. Schwarz, Düsseldorf: Patmos 1979.

37. Siewerth G., Die Analogie des Seienden, in: G. Siewerth, Gesammelte Werke, vol. I, Sein und Wahrheit, ed. F.-A. Schwarz, Düsseldorf: Patmos.

38. Siewerth G., Gesammelte Werke vol. II: Der Thomismus als Identitätssystem, ed. F.-A. Schwarz, Düsseldorf: Patmos 1979.

39. Siewerth G., Martin Heidegger und die Frage nach Gott, in: G. Siewerth, Gesammelte Werke, vol. III: Gott in der Geschichte. Zur Gottesfrage bei Hegel und Heidegger, ed. A. von Stockhausen, Düsseldorf: Patmos, 1971.

40. Siewerth G., Martin Heidegger und die Gottesfrage, in: G. Siewerth, Gesammelte Werke, vol. III.

41. Siewerth G., Schicksal der Metaphysik von Thomas bis Heidegger, Freiburg: Einsiedeln, 2003.

42. Siewerth G., Über das Wunderbare, in: G. Siewerth, Hinführung zur exemplarischen Lehre, Freiburg - Basel - Wien: Herder, 1965.

43. Verweyen H., Ontologische Voraussetzungen des Glaubensaktes, Düsseldorf: Patmos, 1969. 
44. Vetter H., Grundriss Heidegger: Ein Handbuch zu Leben und Werk, Hamburg: Meiner, 2014.

45. Vorgrimler H., Karl Rahner. Gotteserfahrung in Leben und Denken, Darmstadt: WBG 2004.

46. Vorgrimler H., Understanding Karl Rahner: An Introduction to His Life and ought, New York: Crossroad, 1986.

47. Welte B., Auf der Spur des Ewigen, Freiburg - Basel - Wien: Herder, 1965.

48. Welte B., Meister Eckhart. Gedanken zu seinen Gedanken, Freiburg: Herder, 2nd ed. 1992.

49. Welte B., Religionsphilosophie, Freiburg - Basel - Wien: Herder, 2nd ed. 1979.

50. Wierciński A., Inspired Metaphysics? Gustav Siewerth's Hermeneutic Reading of the Onto-Theological Tradition, Toronto: The Hermeneutic Press, 2003.

51. Zaborowski H., Eine Frage von Irre und Schuld. Martin Heidegger und der Nationalsozialismus, Frankfurt am Main: Fischer 2010. 